\title{
O FENÔMENO DE HERANÇA NOS PROCESSSOS TECTÓNICOS
}

B.B.Brito Neves

Os exemplos e as citações de fenômenos de herança tectônica são frequentes na bibliografia, mas sem o respaldo desejável do ponto de vista cientffico.

A íntima conexão dos trendes estruturais Hudsoniano-Greenville - lapetus Apalaches - Atlântico Norte (na América do Norte) e Rio Negro/Juruena - San Ignácio Sansas/Aguapeí - Andes (América do Sul) pode servir de exemplo, para ficar com o lado ocidental. Estas coincidências de trendes já levaram alguns autores a afirmar que os Andes teriam 2,0 Ga. de evolução, o que é exorbitância de afirmação e análise.

Em tempos de Tectônica Global pode parecer herético continuar falando em herança tectônica, apanágio e relicário de naturalistas e descritivistas ("fixistas") de gerações passadas. Para surpresa de muitos há notável acervo bibliográfico da última década sobre o tema, destacando-se os vários trabalhos dos livros Collision Tectonics (COWARD \& RIES, 1986) e Continental Extensional Tectonics (COWARD et al, 1987), e particularmente os artigos de JACKSON (1980; (Nature, 283: 343 346), DEWEY (1988; Tectonics, 7(6):1123-1139). Mais recentemente, SENGOR (1991; EarthSc.Rev., 17:1-201) na comemoração dos 25 anos da Tectônica ao Global concilia o tema com a modernidade cientffica.

Em feições geológicas gerais e em feições lito-estruturais da escala regional e local, em conotações de trende ou geometria, a herança tectônica está marcada pela atuação significativa de tramas preexistentes. Em várias circunstâncias no interior das placas continentais (constituição fisicamente heterogênea, complexa, não monolitica) e da interação de placas, a herança tectônica tem sido consignada.

A) Nas zonas orogenéticas colisionais há uma fraqueza crônica, que sempre leva

Departamento de Geologia Geral, Instituto de Geociências, USP. 
ao colapso extensional, e o final de um ciclo tectônico pode consignar o prenúncio de um novo ciclo Para isto contribuem vários fenômenos geodinâmicos:

a) A supremacia das forças de equilibrio isostático sobre as de convergência.

b) $O$ espessamento exagerado da litosfera não raro conduz a sua deslaminação da astenosfera,

c) A exposição da crosta inferior ao material astenosférico quente.

d) $O$ espessamento da crosta superior (rica em descontinuidades) e da crosta inferior (dúctil) leva a redução da resistência relativa da litosfera.

De forma que desenvolvimentos orogenéticos absolutamente monocíclicos (sem laços com tramas preexistentes e sem deixar rastros) são considerados raros.

B) Nas zonas de convergência sem colisão, o desenvolvimento de arco magmático no continente é fator desencadeante do processo de herança. Nos arcos extensionais, velhas zonas de fraturas são reabertas, e a continuidade do processo de formação da bacia de retroarco pode preludiar uma abertura oceânica.

C) Na separação continental o aproveitamento de antigas descontinuidades é regra. E a recíproca é verdadeira, sendo conhecidos retardamentos de importáncia pela presença de estruturas antigas dispostas em sentido contrário, obstaculando a evolução da margem.

D) No interior dos continentes, na formação e evolução dos riftes - principalmente aqueles do tipo R.L.A., de Litosfera Ativada o aproveitamento das estruturas preexistentes é fundamental. Muitas vezes não há domeamento precedendo rifte. Na estrutura das "síneclises" a carga sedimentar vai estabelecer ações e receber respostas diferentes dos diferentes segmentos crustais sotopostos, e toda a evolução da bacia reflete estas heranças.

É necessário deixar claro que a retomada/reativação de estruturas preexistentes é lugar comum de orógenos, tafrógenos e bacias sedimentares as mais diversas. Mas não necessariamente isto implica em vínculo genético imediato e "in situ" entre as estruturas mais velhas e as mais novas. A herança tectônica é um fato que sobrevive na comunidade cientffica de fronteira.

Por outro lado, o fenômeno de herança não é sistemático, e sim seletivo, e por vezes até caprichoso. Surpreendentemente, algumas estruturas crustais vigorosas são preteridas (à visão de superfície, em relação a outras aparentemente menos importantes). E além disso há muitas edificações orogenéticas e lito-estruturais que parecem independer absolutamente de quaisquer precursores e condicionadores. 